Borneo Journal of Sciences \& Technology, 3(2): 05-15

DOI: http://doi.org/10.3570/bjost.2021.3.2-02

e-ISSN: 2672-7439

(c) 2018, UCTS Publisher.

Submitted: $21^{\text {st }}$ January 2021

Accepted: $26^{\text {th }}$ April 2021

Published: $31^{\text {st }}$ July 2021

\title{
Suspended Road System on Peat: A Case Study in Sibu, Malaysia
}

\author{
*Jen Hua Ling, Huong Hun Ting, Yong Tat Lim, Wen Kam Leong and How Teck Sia \\ School of Engineering and Technology, University College of Technology Sarawak, \\ 96000 Sibu, Sarawak, Malaysia
}

\begin{abstract}
Road construction on peat is challenging due to the characteristics of high compressibility and low shear strength, which lead to excessive settlements and various kinds of distress and damage of pavement. To overcome this problem, the suspended road system can be used. In this study, two types of suspended road systems available in Sibu were investigated, namely suspended slab rigid pavement and suspended flat slab system with the flexible pavement. Desk study and site investigation were carried out on both systems, where their performances were evaluated in terms of the structural responses and the physical distresses of pavements. The purpose was to gain understandings of the system as a reference for the industrial practitioners in selecting suitable systems for road construction on peat. Both the systems performed well on peat and had eliminated the differential settlement of pavements and prevented various kinds of distress and damage associated with it. The rigid pavement made of the suspended slab was found cheaper and more durable than the flexible pavement on the suspended flat slab. Its ride quality was however inferior to the flexible pavement. Also, the space underneath the suspended slab system may be a concern to the neighbouring communities as a habitat for pests and wildlife.
\end{abstract}

Keywords: Suspended road system, flexible pavement, peat, pile foundation, case study.

\section{INTRODUCTION}

In Malaysia, $8 \%$ of the land area $(2,457,730$ ha) is covered with peat. $69.11 \%$ of the area is in East Malaysia, Sarawak (1,697,847 ha)[1]. In Sarawak, Sibu and Mukah divisions cover $35.4 \%$ of the peatland $(600,387 \mathrm{ha})$, which is the largest in the state [1] (Figure 1).

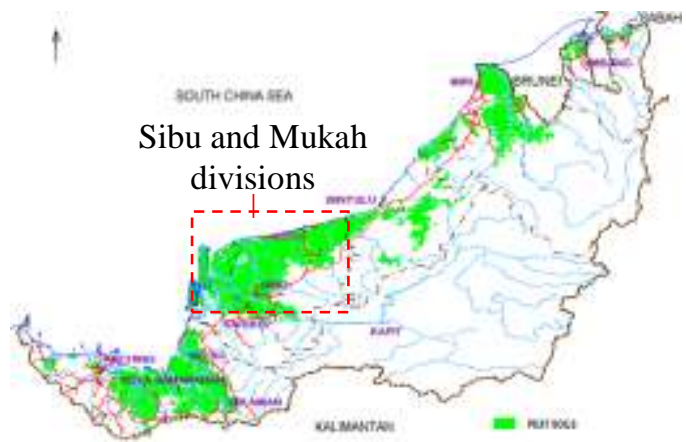

Figure 1: Distribution of peat in Sarawak (Source: Department of Irrigation \& Drainage Sarawak, 2020)

Peat is soft soil rich in fibrous organic matter [2]. It is brownish-black in colour and has distinctive odours [3]. The organic and moisture contents in peat are extremely high [4];[5]. It is predominantly made up of decayed organic matter $(\geq 65 \%)$ and mineral substances
( $\geq 35 \%$ ) [6]. For peat in Sarawak, the contents of natural water and organic can reach $2207 \%$ and $98 \%$ respectively [2].

Peat has high compressibility (compression index, $C_{c}=1.045$ to 1.64 ) and low shear strength (undrained shear strength $C_{u} \leq 10 \mathrm{kPa}$ ) [4];[5];[7]. The groundwater level in peat is rather high, which is normally near the ground surface [7]. These characteristics make the construction on peat challenging, particularly the preconstruction difficulties, post-construction failures, high cost of construction and maintenance, etc. [3].

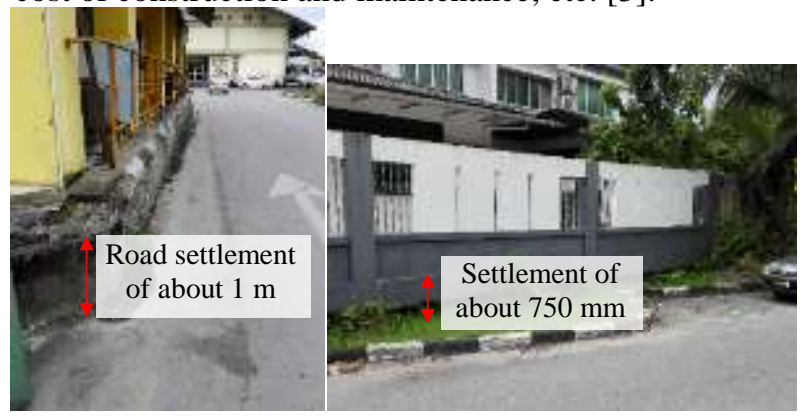

$\begin{array}{ll}\text { (a) Road settlement at a } & \text { (b) Post-construction settlement }\end{array}$ commercial lot of a residential building

Figure 2: Settlement problem of peat in Sibu 
Figure 2 shows the settlement problem of peat. The total settlement can surpass $300 \mathrm{~mm}$ within 1 year of construction and the differential settlements can exceed 1:150 [8]. This can cause instability and affect the service life of the structure building on peat. For that, peat is normally avoided for construction [5]. However, due to the increasing population, scarcity of land and necessity of economic growth, the infrastructure development on peatland is sometimes inevitable [9].

For road construction, the conventional displacement method is commonly used. It involves building road embankments with heavy materials, such as aggregates, rock and other crushed paving materials, to displace the peat for higher bearing capacity of road base. This method is ineffective as the fibres in peat hinder the displacement, and the displaced peat can affect the adjacent structures within 5 times the peat depth [10]. The road suffers serious differential settlement from time to time and requires maintenance, which incurs high maintenance costs in long term [7].

Alternatively, the partial replacement method may be applied. A manageable depth of peat within $3 \mathrm{~m}$ is excavated and replaced with sand fill materials for higher bearing capacity [8]. This method improves the efficiency of displacing peat by (a) removing the fibrous peat deposit near the ground surface and (b) reducing the amount of peat to be displaced [10]. The total settlement would be less than the conventional displacement method, and the differential settlement is normally within $150 \mathrm{~mm}$ in 2 years of construction [7]. However, this settlement can still cause regional distresses that degrade durability and ride quality of road [11]. Moreover, more than $90 \%$ of the peat area in Sibu is deeper than $1.5 \mathrm{~m}$ [12], some are well over $10 \mathrm{~m}$ [7]. This makes the partial replacement method uneconomical.

Another method of road construction is the suspended system. It is a suspended slab system supported by deep foundations (Figure 3). The loads (i.e. self-weight, permanent load, traffic load, etc.) are carried by reinforced concrete (RC) slabs and transferred to the hard stratum underneath the peat through piles. This method is suitable for the peat greater than $3 \mathrm{~m}$ depth [11], which is effective in eliminating the differential settlement. The construction cost is about 50\% higher than the conventional displacement and the partial displacement methods [11].

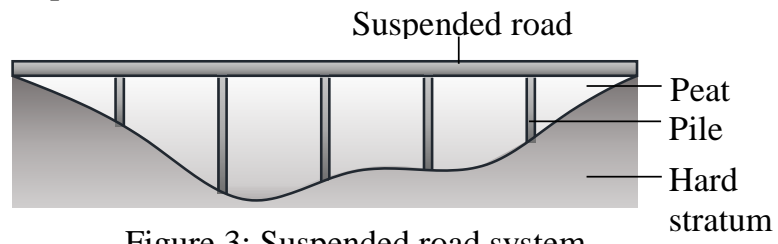

Figure 3: Susnended road svstem

Since 2015, the local authority, Sibu Municipal Council (SMC) had enforced the allowable settlement of a newly developed area to be within $200 \mathrm{~mm}$ in 2 years of construction. For the development on deep peat, this requirement can only be confidently achieved by the suspended road system. This makes it a sensible choice of road construction for the local developers.

With that, a case study was carried out on the suspended road systems available in Sibu to investigate the performance of the systems in various aspects. The purpose was to gain understandings of the systems for reference of the local authorities, developers and professional engineers in selecting suitable suspended road systems for the developments on peat.

\section{MATERIALS AND METHODS}

The study was carried out in two stages; desk study and site investigation. For desk study, documents and research articles were reviewed to acquire the characteristics of peat, the construction methods and the suspended road systems available in Sibu. Consulting the relevant manuals and guides, a rating system was developed to assess the distresses of the pavement. The assessment criteria were ensured objective, explicit, measurable, thorough and without redundant.

Then, a site investigation was conducted to inspect the distresses and damages on the suspended road system using the rating system developed. Visual inspection and on-site measurements were carried out to assess the service conditions of the suspended road systems.

\section{RESULTS AND DISCUSSION}

\section{Structural Response}

There were two types of suspended road systems found in Sibu, namely (a) suspended slab rigid pavement system (hereafter referred to as "SS system") and (b) suspended flat slab with flexible pavement (hereafter referred to as "SFS system") [11]. The former was found at Medan Mall Sibu, while the latter was at Jalan Chew Sik Hiong Sibu (Figure 4). The characteristics of the two systems are presented in Figure 5 and Table 1.

Both systems were supported by piled foundations that transferred the load directly to the hard stratum underneath the peat.

The SS system at Medan Mall was elevated from the peat surface for about $2 \mathrm{~m}$. There was a large space between the ground and the platform levels, which was shaded, wet and overgrown with vegetation. It became a habitat of pests and wildlife like rats, snakes, lizards and mosquitoes, which may be a concern to the neighbourhood nearby.

To overcome the problem, concrete block walls were constructed as barriers along the pedestrian paths to prevent the accessibility of the public and to isolate the wildlife habitat from the community (Figure 6). As for the inaccessible areas, no barrier was provided. Thus far, there was no reported case on the hazards of health and safety associated with it. 
Suspended Road System on Peat: A Case Study in Sibu, Malaysia

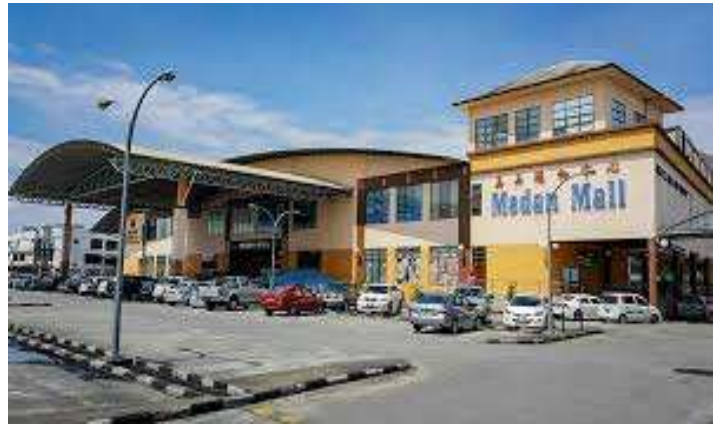

(a) At Medan Mall, Sibu

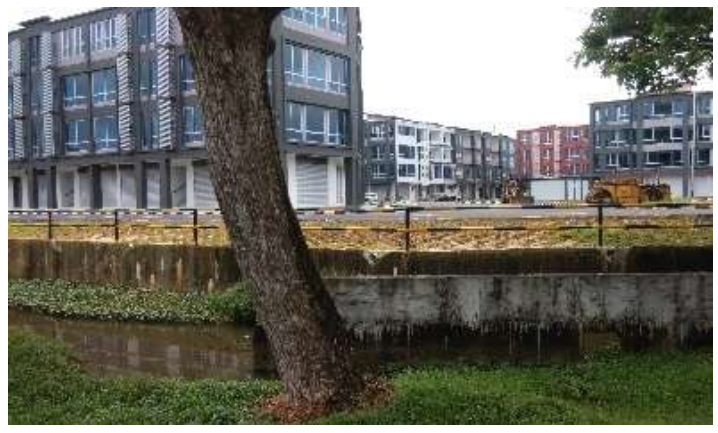

(b) At Jalan Chew Sik Hiong, Sibu

Figure 4: Suspended road system studied

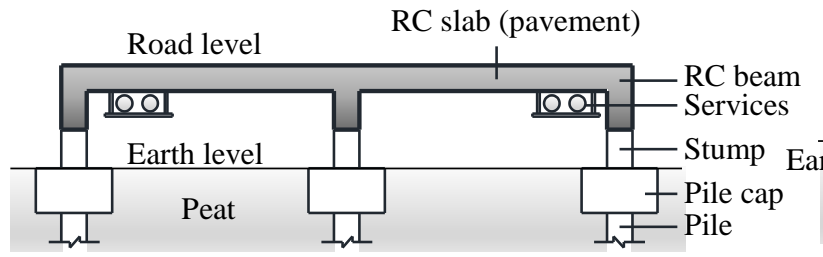

(a) Suspended slab rigid pavement system

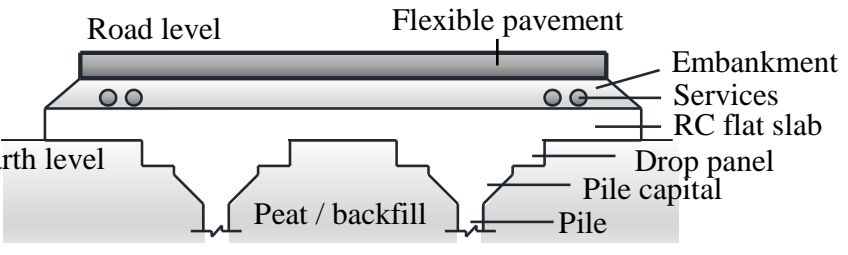

(b) Suspended flat slab with flexible pavement

Figure 5: Types of suspended slab system

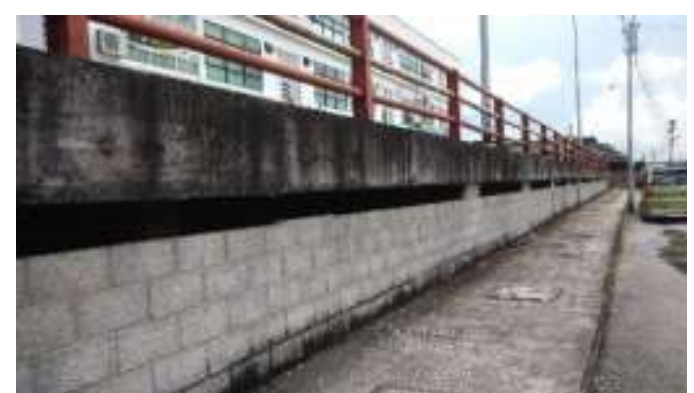

(a) Concrete block wall along pedestrian path

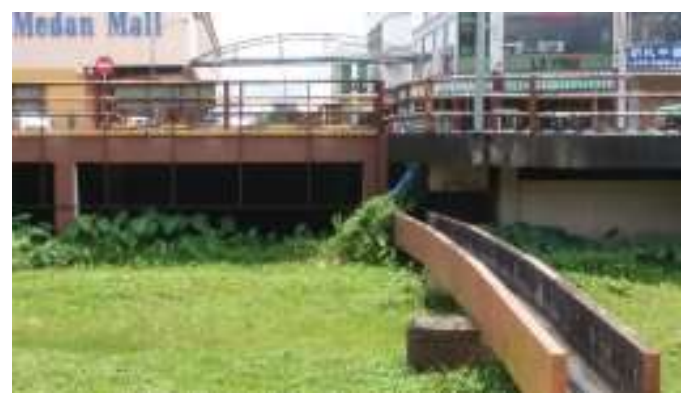

(b) No wall at inaccessible places

Figure 6: Public accessibility control underneath the platform

Table 1: Characteristics of the suspended road system

\begin{tabular}{|c|c|c|}
\hline $\begin{array}{l}\text { Suspended } \\
\text { road system }\end{array}$ & Suspended slab rigid pavement (SS) & $\begin{array}{l}\text { Suspended flat slab with flexible pavement } \\
\text { (SFS) }\end{array}$ \\
\hline $\begin{array}{l}\text { Location / } \\
\text { Coordinates }\end{array}$ & Medan Mall, Sibu / $2.2928^{\circ} \mathrm{N}, 111.8421^{\circ} \mathrm{E}$ & $\begin{array}{c}\text { Jalan Chew Sik Hiong, Sibu / } 2.2940^{\circ} \mathrm{N} \\
111.8358^{\circ} \mathrm{E}\end{array}$ \\
\hline Description & $\begin{array}{l}\text { A platform made of RC slabs and beam. } \\
\text { Loads were transferred to the ground through } \\
\text { the piled foundations comprising the stumps, } \\
\text { pile caps and piles. }\end{array}$ & $\begin{array}{l}\text { A platform made of RC flat slab sitting on } \\
\text { piles. No beam, stump and pile cap were } \\
\text { required. Loads were transferred to the ground } \\
\text { through the piles. }\end{array}$ \\
\hline $\begin{array}{l}\text { Pile } \\
\text { foundation }\end{array}$ & $\begin{array}{l}250 \mathrm{~mm} \text { RC square pile (capacity } \approx 40 \text { tonnes) } \\
\text { with } 3 \mathrm{~m} \text { to } 8.5 \mathrm{~m} \text { spacing. }\end{array}$ & $\begin{array}{l}200 \mathrm{~mm} \text { RC square pile (capacity } \approx 30 \text { tonnes) } \\
\text { with } 2 \mathrm{~m} \text { spacing. }\end{array}$ \\
\hline $\begin{array}{l}\text { Pavement } \\
\text { type }\end{array}$ & RC slab acted as the rigid pavement. & $\begin{array}{l}\text { Flexible pavement (bituminous road) was } \\
\text { constructed on a reinforced concrete catchment }\end{array}$ \\
\hline $\begin{array}{l}\text { Platform } \\
\text { level }\end{array}$ & $\begin{array}{l}\text { The road platform was elevated from the peat } \\
\text { surface for about } 2 \mathrm{~m} .\end{array}$ & $\begin{array}{l}\text { The road platform was directly in contact with } \\
\text { the peat surface. }\end{array}$ \\
\hline $\begin{array}{l}\text { Drainage } \\
\text { system }\end{array}$ & RC drain was used. & RC drain was used. \\
\hline $\begin{array}{l}\text { Services and } \\
\text { utilities }\end{array}$ & $\begin{array}{l}\text { The services and utilities were fixed under the } \\
\text { RC slab above the peat. }\end{array}$ & $\begin{array}{l}\text { The services and utilizes were laid under the } \\
\text { flexible pavement above the flat slab. }\end{array}$ \\
\hline
\end{tabular}


The SFS system at Jalan Chew Sik Hiong was constructed in contact with the ground surface. Backfill was done to the intended platform level during the construction as a part of formworks. The system had no beam. Thus, less formwork and steelworks were required, and this simplified the construction process of the superstructure

However, to prevent failures due to punching shear and excessive deflection, a shorter span and thicker slab was used in SFS system. Drop panels and pile capitals were provided to increase the effective shear area for higher resistance to punching shear at the pile perimeter. The piles were closely spaced at $2 \mathrm{~m}$, as compared with the $3 \mathrm{~m}$ to $8.5 \mathrm{~m}$ spacing of the SS system (Table 1). This increased the total number of pile driving points, and hence, the piling works would require a longer duration.

The SFS system at Jalan Chew Sik Hiong was used to support the flexible pavement and its embankment. For that, the permanent loads acting on the SFS system were higher than the SS system that used the slab as the rigid pavement. Nevertheless, it gave a better ride quality than the rigid pavement.

For the SS system at Medan Mall, the services and utilities were placed underneath the platform. The postconstruction maintenance and upgrading works of the services were done under the platform with minimum interruption of traffic flow. There was ample working space underneath the platform despite the poor working environment, which was wet, dark, poor hygiene and may have safety concerns with the wildlife. Some maintenance works may involve hacking of RC slab to create passages for the services.

As for the SFS system at Jalan Chew Sik Hiong, the services and utilities were laid within the road embankment between the flexible pavement and the flat slab. The post-construction maintenance and upgrading works would have been done from above and this would interrupt the traffic flow.

\section{Distress and Damage}

Visual inspection was performed on-site to assess the service conditions of the SS and SFS systems. The distresses and damages on the rigid and flexible pavements were identified and rated based on the levels of severity outlined in Tables A1 and A2 respectively, as developed from the desk study.

The distresses found on the rigid pavement at Medan Mall included surface deterioration, patching deterioration, polished aggregate, longitudinal cracks and transverse cracks (Figure 7) at low to medium levels of severities (Table 2). The distresses were mainly caused by (a) repeated abrasions by traffic, (b) expansion and shrinkage movement due to daily thermal cycle, (c) progressive deterioration by traffic loads and (d) poor bond between the construction joints.

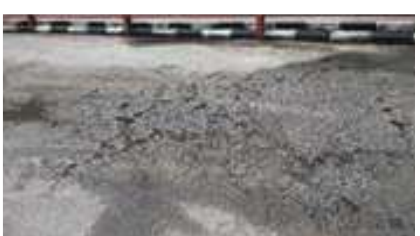

(a) Surface deterioration

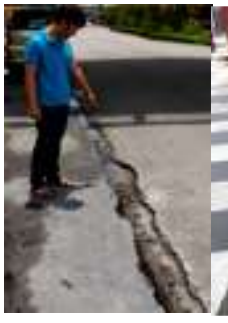

(c) Patching

deterioration

(d)

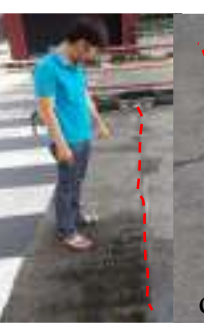

Cracks at (e) joint

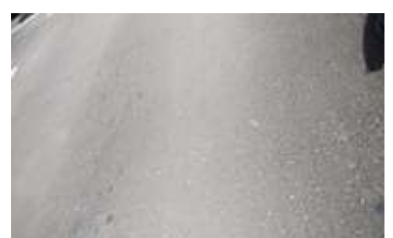

(b) Polished aggregate
Figure 7: Distresses on rigid pavement at Medan Mall

Table 2: Distress on the rigid pavement at Medan Mall

\begin{tabular}{|l|c|c|c|c|}
\hline \multirow{2}{*}{ Distress } & \multicolumn{4}{|c|}{ Severity level*1 } \\
\hline & N & L & M & H \\
\hline Blowup/ Buckling & $\sqrt{ }$ & & & \\
\hline Corner break & $\sqrt{ }$ & & & \\
\hline Divided slab & $\sqrt{ }$ & & & \\
\hline Faulting & $\sqrt{ }$ & & & \\
\hline Joint seal damage & $\sqrt{ }$ & & & \\
\hline Lane/ shoulder drop-off & $\sqrt{ }$ & & & \\
\hline Patching deterioration & & & $\sqrt{ }$ & \\
\hline Polished aggregate*2 & & & $\sqrt{ }$ & \\
\hline Popouts*2 & $\sqrt{ }$ & & & \\
\hline Punchout & $\sqrt{ }$ & & & \\
\hline Scaling, map cracking, crazing & $\sqrt{ }$ & & & \\
\hline Shrinkage cracks*2 & $\sqrt{ }{ }^{*}$ & & & \\
\hline Spalling corner & $\sqrt{ }$ & & & \\
\hline Spalling joint & $\sqrt{ }$ & & & \\
\hline Transverse cracks & & $\sqrt{ }$ & & \\
\hline Longitudinal Cracks & & $\sqrt{ }$ & & \\
\hline Surface Deterioration & & & $\sqrt{ }$ & \\
\hline Shattered Slab & $\sqrt{ }$ & & \\
\hline
\end{tabular}

*l N-Not detected, L-Low severity, $M-$ Medium severity, $H$-High severity

${ }^{2}$ Severity level not explicitly defined in Table A1. It was rated by the impression of the inspector.

The distresses found on the flexible pavement at Jalan Chew Sik Hiong were potholes, ravelling and patching (Figure 8) at moderate severity (Table 3 ). The 
distresses were mainly due to (a) repeated abrasions by traffic, (b) progressive deterioration by traffic loads, (c) seepage of water and (d) poor binding of asphalt pavement.

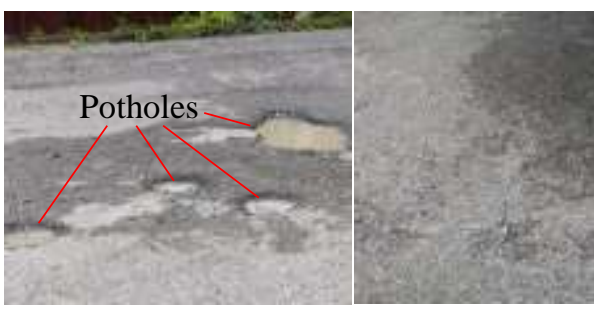

(a) Potholes (b) Ravelling

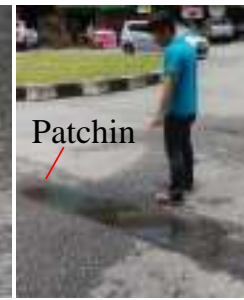

(c) Patching
Figure 8: Distresses on flexible pavement at Jalan Chew Sik Hiong

Table 3: Distress on the pavement at Jalan Chew Sik

Hiong

\begin{tabular}{|l|c|c|c|c|}
\hline \multirow{2}{*}{ Distress } & \multicolumn{4}{|c|}{ Severity level*1 } \\
\hline & N & L & M & H \\
\hline Longitudinal Cracking & $\sqrt{ }$ & & & \\
\hline Pavement Edge Cracking & $\sqrt{ }$ & & & \\
\hline Transverse Cracking & $\sqrt{ }$ & & & \\
\hline Alligator Cracking & $\sqrt{ }$ & & & \\
\hline Rutting & $\sqrt{ }$ & & & \\
\hline Shoving & $\sqrt{ }$ & & & \\
\hline Distortion & $\sqrt{ }$ & & & \\
\hline Bleeding & $\sqrt{ }$ & & & \\
\hline Potholes & & & $\sqrt{ }$ & \\
\hline Ravelling & & & $\sqrt{ }$ & \\
\hline Block cracking & $\sqrt{ }$ & & & \\
\hline Bumps and sags & $\sqrt{ }$ & & & \\
\hline Corrugation & $\sqrt{ }$ & & & \\
\hline Depression & $\sqrt{ }$ & & & \\
\hline Lane/ shoulder drop-off & $\sqrt{ }$ & & & \\
\hline Patching deterioration & & & $\sqrt{ }$ & \\
\hline Polished aggregate*2 & $\sqrt{ }$ & & & \\
\hline Slippage cracking & $\sqrt{ }$ & & \\
\hline
\end{tabular}

*I $N$ - Not detected, $L-$ Low severity, $M-$ Medium severity, $H$-High severity

${ }^{2}$ Severity level not explicitly defined in Table A2. It was rated by the impression of the inspector.

For laying the services under the pavement, numerous places of the flexible pavement had been cut and patched. This directly affected the durability and ride quality of the pavement. For the uneven surface level and inhomogeneity of the patching with the existing pavement, stress tended to concentrate at the joint, and this caused the patching area to deteriorate rapidly. Maintenance would be required from time to time.

In general, both the rigid and flexible pavements were in good condition. The distresses were localized, not critical and can be repaired easily. No defect was found on the main structural elements of the systems.

The two suspended slab systems performed well in controlling the differential settlement of pavement, which had prevented the distresses associated with it.

This was also partially attributed to the application of the pavement, which was light-medium duty without significant traffic loads, as follows:

a. The pavements provided access to commercial areas, mainly serving light-medium duty vehicles (Class 1 to $6,<11,793 \mathrm{~kg}$ or 26,000 pounds),

b. Based on the habit of local road users, and due to numerous junctions along a short stretch of road, the vehicle speed barely exceeded $60 \mathrm{~km} / \mathrm{hr}$,

c. The road gradient was rather flat $(<1: 10)$

\section{Comparison of Suspended Road System}

Table 4 compares the designs of the two suspended road systems. In general, the conventional RC suspended slab system was used at Medan Mall. The slab itself was the rigid pavement. Meanwhile, Jalan Chew Sik Hiong was a suspended flat slab system without beams. The flexible pavement was constructed on the flat slab.

According to Ting (2016) [11], the construction cost of the SS system at Medan Mall was estimated 53.6\% to $67.2 \%$ cheaper than the SFS system at Jalan Chew Sik Hiong. This could be attributed to the following reasons: a. The flat slab was by nature more expensive than the conventional RC slab due to shorter allowable spans, thicker slabs and more pilling points.

b. The flexible pavement and its embankment increased the permanent loads acting on the suspended system.

In terms of strength and durability, the flexible pavement made of asphalt mix had lower strength, easier to deteriorate and had a shorter life span than the rigid pavement made of reinforced concrete. The flexible pavement required regular maintenance, but the repairing works were cheaper, easier and faster than rigid pavement. The maintenance works done on the pavement inevitably interrupted the traffic flow.

For the smooth surface, the flexible pavement gave a superior ride quality over the rigid pavement. However, this was not critical for a road servicing commercial areas with a dense population of pedestrians and the general vehicle speed barely exceeded $60 \mathrm{~km} / \mathrm{hr}$.

On the economic aspect, the SS system at Medan Mall incurred lower costs of construction and maintenance in long term than the SFS system at Jalan Chew Sik Hiong. 
Suspended Road System on Peat: A Case Study in Sibu, Malaysia

Table 4: Comparison of the suspended road systems

\begin{tabular}{|c|c|c|}
\hline $\begin{array}{l}\text { Suspended } \\
\text { road system }\end{array}$ & Suspended slab rigid pavement (SS) & $\begin{array}{l}\text { Suspended flat slab with flexible pavement } \\
\text { (SFS) }\end{array}$ \\
\hline $\begin{array}{l}\text { Design } \\
\text { considerations }\end{array}$ & 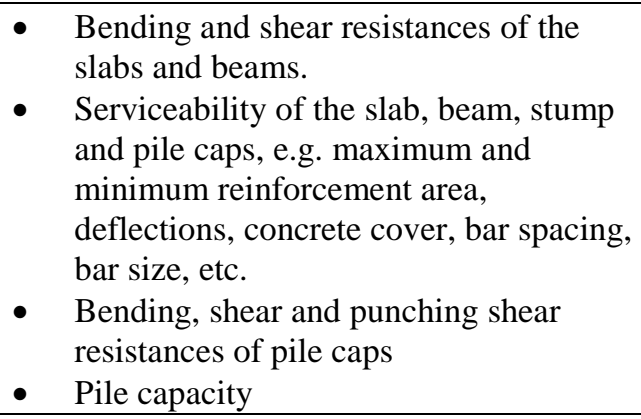 & 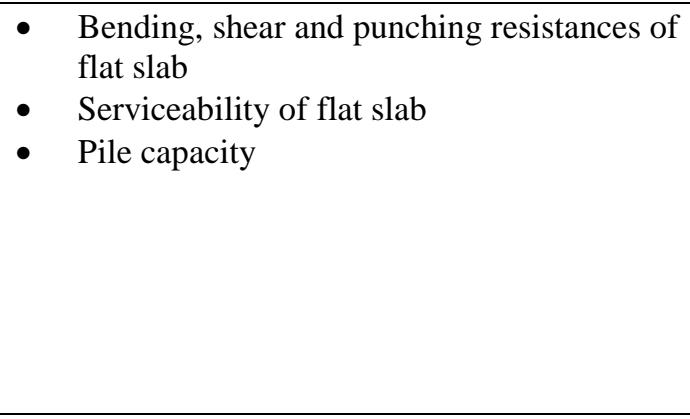 \\
\hline Advantages & $\begin{array}{l}\text { - Long spans of beam and slab may be } \\
\text { used, where piles may be spaced } \\
\text { further. } \\
\text { - High durability of rigid pavement, less } \\
\text { maintenance required } \\
\text { - Settlement and differential settlement of } \\
\text { road can be eliminated } \\
\text { Maintenance works on utilities and } \\
\text { services would not interrupt the traffic } \\
\text { flow }\end{array}$ & $\begin{array}{l}\text { - Fewer formworks and steelworks were } \\
\text { required. } \\
\text { - The flexible pavement gave smooth riding. } \\
\text { - Settlement and differential settlement of } \\
\text { road can be eliminated }\end{array}$ \\
\hline Disadvantages & $\begin{array}{l}\text { Habitat for pests underneath the } \\
\text { suspended system } \\
\text { - } \quad \begin{array}{l}\text { More formworks and steelworks } \\
\text { required }\end{array} \\
\text { - } \quad \begin{array}{l}\text { Longer construction duration for the } \\
\text { superstructure }\end{array} \\
\text { - } \begin{array}{l}\text { Poor ride quality due to rigid road } \\
\text { surface }\end{array}\end{array}$ & $\begin{array}{l}\text { - A thicker flat slab or the smaller spacing of } \\
\text { piles was required } \\
\text { - Longer construction duration for } \\
\text { substructure } \\
\text { - Underground services cause numerous } \\
\text { areas to be patched. } \\
\text { - Poor resistance of road surface to abrasion } \\
\text { Maintenance of flexible pavement is } \\
\text { required more frequently } \\
\text { Maintenance works on utilities and services } \\
\text { interrupts the traffic flow }\end{array}$ \\
\hline
\end{tabular}

\section{CONCLUSION}

In this study, two types of suspended road systems available in Sibu were studied, which were suspended slab rigid pavement system at Medan Mall and suspended flat slab system with the flexible pavement at Jalan Chew Sik Hiong. The purpose was to acquire the characteristics of the systems as a reference to the industrial practitioners in selecting a suitable road construction system for the development on peats.

The two systems were evaluated in terms of the structural responses of the systems and the physical distress of the pavement. Both systems performed well on peat and were effective to prevent excessive settlement and eliminate the differential settlement of the pavement, which subsequently prevented various kinds of distress associated with it and increased the durability of the pavement.

The suspended slab rigid pavement system was found cheaper and more durable than the suspended flat slab system with the flexible pavement. Considering solely the cost incurred in long term, it would be a better option than the suspended flat slab system. However, there may be some concerns about the habitat of pests and wildlife underneath the suspended slab, which may bring harm to the neighbouring communities. With that, the industrial practitioners shall adopt it wisely.

\section{REFERENCES}

[1] Construction Research Institute of Malaysia (CREAM), 2015. Guidelines for construction on peat and organic soils in Malaysia, CIDB Malaysia.

[2] Huat, B.B.K., S. Kazemian, A. Prasad and M. Barghchi, 2011. State of an art review of peat: General perspective, International Journal of the Physical Sciences, 6(8): 1988-1996.

[3] Ling, J.H., S. Mohd, S.A. Ahmad Tajudin, S.N. Ali Mohamad, I. Bakar, M.I. Mohd Masirin, A. Zainorabidin and A.A.W. Mahmood, 2016. 
Construction of infrastructure on peat: case studies and lessons learned, Matec Web of Conferences, 47, 03014: 1-6.

[4] Mahmod, A.A.W., S. Mohd, M.I. Mohd Masirin, S. A. Ahmad Tajudin, I. Bakar, A. Zainorabidin, A. Zulwali Kifli and J.H. Ling, 2016. Construction of buildings on peat: case studies and lessons learned, Matec Web of Conference, 47, 03013: 1-5.

[5] Kalantari B., 2013. Civil engineering significant of peat, Global Journal of Researches in Engineering 13(2).

[6] Salimin, M.I., S. Gandaseca, O.H. Ahmed and N.M. Ab. Majid, 2010. Comparison of selected chemical properties of peat swamp soil before and after timber harvesting, American Journal of Environmental Sciences, 6(2): 164-167.

[7] Tang, V.C.K., 2016. Peat and organic soils challenges in road construction in Sarawak: JKR Sarawak experience. Proceeding of the 15th International Peat Congress 2016, Kuching, Malaysia, pp: $613-618$.
[8] Zainorabidin, A., D.C. Wijeyesekera, 2007. Geotechnical challenges with Malaysian peat. Proceeding of the Advances in Computing and Technology Conference (AC\&T), 2nd Annual Conference, Docklands, London, 2007.

[9] Kolay, P.K., H.Y. Sii, S.N.L. Taib, 2011. Tropical peat soil stabilization using class $F$ pond ash from coal fired power plant, International Scholarly and Scientific Research \& Innovation. 5(2): 71-75.

[10] Types of construction, https://www.roadex.org/elearning/lessons/roads-on-peat/types-ofconstruction/\#: :text=The\%20'progressive\%20disp lacement'\%2C\%20or,the\%20type\%20of\%20peat $\%$ 20below, accessed on 20 Jan 2020.

[11] Ting H.H., 2016. Comparison of suspended road system in sibu town (case study), Final year project report. School of Engineering and Technology, University College of Technology Sarawak.

[12] Sa'don, N.M., A.R. Abdul Karim, W.Jaol, W.H. Wan Lili, 2015. Sarawak peat characteristics and heat treatment, UNIMAS e-Journal of Civil Engineering 5(3); 6-1.

\section{APPENDICES}

Table A1: Distresses in rigid pavement [11]

\begin{tabular}{|c|c|c|c|c|c|}
\hline \multirow[t]{2}{*}{ Distress } & \multirow[t]{2}{*}{ Description } & \multicolumn{4}{|c|}{ Severity } \\
\hline & & Low (L) & \multicolumn{2}{|c|}{ Medium (M) } & $\operatorname{High}(\mathrm{H})$ \\
\hline $\begin{array}{l}\text { Blowup/ } \\
\text { Buckling }\end{array}$ & $\begin{array}{l}\text { Occurs in hot weather, usually } \\
\text { at a transverse crack or joint } \\
\text { that is insufficient for the } \\
\text { expansion of the slab. }\end{array}$ & - Decent ride quality & \multicolumn{2}{|c|}{ - Fair ride quality } & - Poor ride quality \\
\hline Corner break & $\begin{array}{l}\text { Crack that intersects the joints } \\
\text { at a distance } \leq 1 / 2 \text { slab length } \\
\text { on both sides measured from } \\
\text { the corner of the slab, which is } \\
\text { due to load repetition and loss } \\
\text { of support and curling stresses. }\end{array}$ & $\begin{array}{l}\text { - Crack width }<1 / 8 \\
\text { inches }(3.18 \mathrm{~mm}) \\
\text { that show no } \\
\text { evidence of faulting } \\
\text { - Loss of aggregate } \\
\text { interlock or the } \\
\text { intrusion of debris. }\end{array}$ & \multicolumn{2}{|c|}{$\begin{array}{l}\text { - Crack width } 1 / 8-1 / 4 \\
\text { inches }(3.18-6.35 \\
\text { mm) that exhibit little } \\
\text { or no faulting or } \\
\text { evidence of intrusion } \\
\text { of debris. }\end{array}$} & $\begin{array}{l}\text { - } \text { Crack > 1/4 inches } \\
(6.35 \mathrm{~mm}) \text { that } \\
\text { show loss of } \\
\text { aggregate interlock, } \\
\text { - Obvious intrusion } \\
\text { of water and debris } \\
\text { - Faulting and } \\
\text { spalling may also } \\
\text { occur. }\end{array}$ \\
\hline \multirow[t]{5}{*}{ Divided slab } & \multirow{5}{*}{$\begin{array}{l}\text { The slab is divided by cracks } \\
\text { into four or more pieces due to } \\
\text { overloading and inadequate } \\
\text { support. }\end{array}$} & Severity of & \multicolumn{3}{|c|}{ Number of pieces in cracked slab } \\
\hline & & majority of cracks & $4-5$ & $6-8$ & $>8$ \\
\hline & & Mild & Low & Low & Medium \\
\hline & & Moderate & Low & Medium & High \\
\hline & & \begin{tabular}{|c|} 
Severe \\
\end{tabular} & Medium & High & \begin{tabular}{|l|} 
High \\
\end{tabular} \\
\hline Faulting & $\begin{array}{l}\text { Differential displacement of } \\
\text { abutting slabs at joint or crack } \\
\text { creating a "step" deformation } \\
\text { in the pavement surface. }\end{array}$ & $\begin{array}{l}\text { - Difference } \text { in } \\
\text { elevation } 3-10 \\
\text { mm }\end{array}$ & \multicolumn{2}{|c|}{$\begin{array}{l}\text { - } \text { Difference in } \\
\text { elevation range } 1-20 \\
\text { mm }\end{array}$} & $\begin{array}{l}\text { - } \text { Difference in } \\
\text { elevation } \geq 20 \mathrm{~mm} \text {. }\end{array}$ \\
\hline $\begin{array}{ll}\text { Joint } & \text { seal } \\
\text { damage } & \end{array}$ & $\begin{array}{l}\text { The condition that enables soil } \\
\text { or rocks to accumulate in the } \\
\text { joints or allow significant } \\
\text { water infiltration. }\end{array}$ & $\begin{array}{l}\text { - Joint realant } \\
\text { performing } \text { well } \\
\text { with minor damage, } \\
\text { or } \\
\end{array}$ & \multicolumn{2}{|c|}{$\begin{array}{l}\text { - Joint sealer is in } \\
\text { place, but water } \\
\text { access is possible } \\
\text { through } \\
\text { visible }\end{array}$} & $\begin{array}{l}\text { - Joint sealant is in } \\
\text { poor condition with } \\
\text { one or more severe } \\
\text { damage, }\end{array}$ \\
\hline
\end{tabular}


Suspended Road System on Peat: A Case Study in Sibu, Malaysia

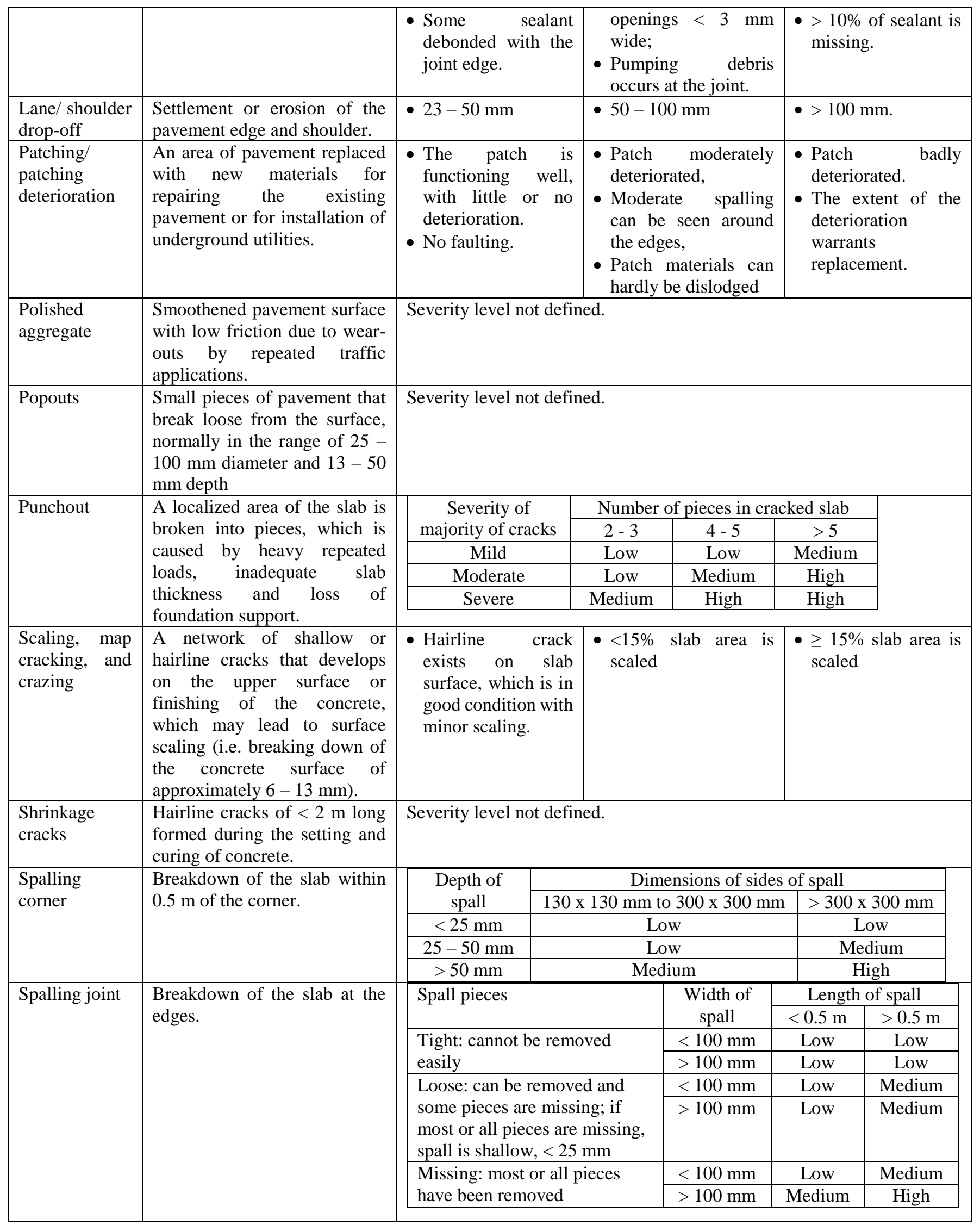


Suspended Road System on Peat: A Case Study in Sibu, Malaysia

\begin{tabular}{|c|c|c|c|c|}
\hline $\begin{array}{l}\text { Transverse } \\
\text { cracking }\end{array}$ & $\begin{array}{l}\text { Cracks predominantly } \\
\text { perpendicular to the pavement. }\end{array}$ & $\begin{array}{l}\text { - Crack widths < } 3 \\
\text { mm, no spalling } \\
\text { and no measurable } \\
\text { faulting; or } \\
\text { - Well-sealed, crack } \\
\text { with negligible } \\
\text { width. }\end{array}$ & $\begin{array}{l}\text { - Crack width } 3-6 \\
\text { mm, or } \\
\text { - faulting up to } 6 \mathrm{~mm} \text {. }\end{array}$ & $\begin{array}{l}\text { - Crack width or } \\
\text { faulting } \geq 6 \mathrm{~mm}\end{array}$ \\
\hline $\begin{array}{l}\text { Longitudinal } \\
\text { Cracking }\end{array}$ & $\begin{array}{l}\text { Cracks predominantly parallel } \\
\text { to the pavement. }\end{array}$ & $\begin{array}{l}\text { - Crack widths < } 3 \\
\text { mm, no spalling } \\
\text { and no measurable } \\
\text { faulting; or } \\
\text { - Well-sealed, crack } \\
\text { with negligible } \\
\text { width. }\end{array}$ & $\begin{array}{l}\text { - Crack width } 3-6 \\
\text { mm, or } \\
\text { - faulting up to } 6 \mathrm{~mm} \text {. }\end{array}$ & $\begin{array}{l}\text { - Crack width or } \\
\text { faulting } \geq 6 \mathrm{~mm}\end{array}$ \\
\hline $\begin{array}{l}\text { Surface } \\
\text { Deterioration }\end{array}$ & $\begin{array}{l}\text { Exposure of aggregate and } \\
\text { disintegration of wearing } \\
\text { surface. }\end{array}$ & & - $1 / 4-1 / 2$ inches deep. & - > 1/2 inches deep. \\
\hline Shattered Slab & $\begin{array}{l}\text { Longitudinal and transverse } \\
\text { cracks that divide the slab into } \\
\text { four pieces }\end{array}$ & & $\begin{array}{l}\text { - The slab is broken } \\
\text { into pieces with some } \\
\text { interlock remaining, } \\
\text { - Crack width < } 1 / 4 \\
\text { inches. }\end{array}$ & $\begin{array}{l}\text { - The slab is broken } \\
\text { into pieces that are } \\
\text { acting } \\
\text { independently, } \\
\text { - Crack width > 1/4 } \\
\text { inches. }\end{array}$ \\
\hline
\end{tabular}

Table A2: Distresses in flexible pavement [11]

\begin{tabular}{|c|c|c|c|c|}
\hline \multirow[t]{2}{*}{ Distress } & \multirow[t]{2}{*}{ Description } & \multicolumn{3}{|c|}{ Severity } \\
\hline & & Low (L) & Medium (M) & $\operatorname{High}(\mathrm{H})$ \\
\hline $\begin{array}{l}\text { Longitudinal } \\
\text { Cracking }\end{array}$ & $\begin{array}{l}\text { Cracks predominantly parallel } \\
\text { to the pavement near the wheel } \\
\text { path. }\end{array}$ & $\begin{array}{l}\text { - Nonfilled crack } \\
\text { width }<5 \mathrm{~mm} \text {, or } \\
\text { - Filled crack of any } \\
\text { width }\end{array}$ & $\begin{array}{l}\text { - Crack surrounded by } \\
\text { light random cracks } \\
\text { - Nonfilled crack width } \\
5-20 \mathrm{~mm} \text {, or } \\
\text { - Filled crack of any } \\
\text { width }\end{array}$ & $\begin{array}{l}\text { - Severe spalling } \\
\text { - Unsealed crack } \\
\text { width } \geq 20 \mathrm{~mm}\end{array}$ \\
\hline $\begin{array}{l}\text { Pavement } \\
\text { Edge Cracking }\end{array}$ & $\begin{array}{l}\text { Longitudinal cracks within } 0.5 \\
\mathrm{~m} \text { of the fog line. It may be in } \\
\text { crescent shape intersecting the } \\
\text { pavement edge }\end{array}$ & $\begin{array}{l}\text { - Single crack with } \\
\text { no spalling } \\
\text { - Unsealed crack } \\
\text { width }<5 \mathrm{~mm}\end{array}$ & $\begin{array}{l}\text { - Single or multiple } \\
\text { cracks with moderate } \\
\text { spalling } \\
\text { - Unsealed crack width } \\
5-20 \mathrm{~mm} \text {. }\end{array}$ & $\begin{array}{l}\text { - Single or multiple } \\
\text { cracks with severe } \\
\text { spalling, or } \\
\text { - Unsealed crack } \\
\text { width > } 20 \mathrm{~mm} \\
\text { - Alligator cracks }\end{array}$ \\
\hline $\begin{array}{l}\text { Transverse } \\
\text { Cracking }\end{array}$ & $\begin{array}{l}\text { Cracks predominantly } \\
\text { perpendicular to the pavement. }\end{array}$ & $\begin{array}{l}\text { - Unsealed crack } \\
\text { width }<5 \mathrm{~mm} \text {, or } \\
\text { - Sealed crack in } \\
\text { good condition with } \\
\text { negligible width. }\end{array}$ & $\begin{array}{l}\text { - Crack width } 5-20 \\
\text { mm adjacent with } \\
\text { random cracks of low } \\
\text { severity. }\end{array}$ & $\begin{array}{l}\text { - Crack width }>20 \\
\text { mm, or } \\
\text { - Crack width } \leq 20 \\
\text { mm adjacent with } \\
\text { moderate to high } \\
\text { severity random } \\
\text { cracks }\end{array}$ \\
\hline $\begin{array}{l}\text { Alligator } \\
\text { Cracking }\end{array}$ & $\begin{array}{l}\text { Cracks form a network of } \\
\text { multi-sided blocks that look } \\
\text { like the skin of an alligator. } \\
\text { The cracks develop into many- } \\
\text { sided, sharp-angled pieces, } \\
\text { usually less than } 0.3 \mathrm{~m} \text { on the } \\
\text { longest side. }\end{array}$ & $\begin{array}{l}\text { - An area of cracks } \\
\text { without or with } \\
\text { only a few } \\
\text { connecting cracks } \\
\text { - Cracks are not } \\
\text { spalled or sealed } \\
\text { - Pumping is not } \\
\text { distinct. }\end{array}$ & $\begin{array}{l}\text { - Interconnected } \\
\text { cracks forming a } \\
\text { complete block } \\
\text { pattern } \\
\text { - Slight spalling } \\
\text { - No pumping }\end{array}$ & $\begin{array}{l}\text { - Interconnected } \\
\text { cracks forming a } \\
\text { complete block } \\
\text { pattern } \\
\text { - Moderate to severe } \\
\text { spalling } \\
\text { - Pieces may move } \\
\text { - Pumping may exist. }\end{array}$ \\
\hline
\end{tabular}


Suspended Road System on Peat: A Case Study in Sibu, Malaysia

\begin{tabular}{|c|c|c|c|c|}
\hline Rutting & $\begin{array}{l}\text { Longitudinal depressions } \\
\text { occur in the wheel paths due to } \\
\text { repeated loadings, combined } \\
\text { with lateral movement of the } \\
\text { pavement materials. }\end{array}$ & - Rut depth $<10 \mathrm{~mm}$. & $\begin{array}{l}\text { - Rut depth } 10-20 \\
\text { mm. }\end{array}$ & - Rut depth > $20 \mathrm{~mm}$. \\
\hline Shoving & $\begin{array}{l}\text { Localized longitudinal } \\
\text { displacement of pavement } \\
\text { surface caused by braking or } \\
\text { accelerating vehicles. }\end{array}$ & - Decent ride quality & - Fair ride quality. & - Poor ride quality \\
\hline Distortion & $\begin{array}{l}\text { Any deviation of the pavement } \\
\text { surface from its original shape } \\
\text { other than shoving and rutting, } \\
\text { which is generally due to } \\
\text { densification, consolidation, } \\
\text { swelling, creep or slipping of } \\
\text { the surface or foundation. }\end{array}$ & $\begin{array}{l}\text { - Slight waves, sags, } \\
\text { humps, } \\
\text { corrugations or } \\
\text { wash boarding of } \\
\text { the pavement }\end{array}$ & $\begin{array}{l}\text { - Noticeable swaying } \\
\text { motion, good car } \\
\text { control. }\end{array}$ & $\begin{array}{l}\text { - Fair to poor car } \\
\text { control and the } \\
\text { vehicles have to } \\
\text { slow down from } \\
\text { normal speed. }\end{array}$ \\
\hline Bleeding & $\begin{array}{l}\text { Excess bituminous binder on } \\
\text { the pavement surface, which } \\
\text { creates a shiny, glass-like, } \\
\text { reflective surface that may be } \\
\text { tacky to the touch. }\end{array}$ & $\begin{array}{l}\text { - Slight degree and } \\
\text { noticeable during a } \\
\text { few days of the } \\
\text { year. } \\
\text { - Does not stick to } \\
\text { shoes or vehicles. }\end{array}$ & $\begin{array}{l}\text { - Distinctive } \\
\text { appearance with free, } \\
\text { excess asphalt and } \\
\text { stick to the shoes or } \\
\text { vehicles only a few } \\
\text { weeks of the year. }\end{array}$ & $\begin{array}{l}\text { - Gives pavement } \\
\text { surface a wet look } \\
\text { and stick to the } \\
\text { shoes and vehicles } \\
\text { at least several } \\
\text { weeks of the year. }\end{array}$ \\
\hline \multirow[t]{5}{*}{ Potholes } & \multirow{5}{*}{$\begin{array}{l}\text { Bowl-shaped holes of various } \\
\text { sizes in the pavement surface. }\end{array}$} & \multirow{5}{*}{\begin{tabular}{|c|c|}
$\begin{array}{c}\text { Maximum } \\
\text { depth }\end{array}$ &
\end{tabular}} & \multicolumn{2}{|c|}{ Average diameter $(\mathrm{mm})$} \\
\hline & & & \begin{tabular}{c|c}
$\begin{array}{c}100-200 \\
\mathrm{~mm}\end{array}$ & $\begin{array}{c}200-450 \\
\mathrm{~mm}\end{array}$
\end{tabular} & $\begin{array}{c}450-750 \\
\mathrm{~mm}\end{array}$ \\
\hline & & & \begin{tabular}{l|l} 
Low & Mild \\
\end{tabular} & Medium \\
\hline & & & \begin{tabular}{|l|l} 
Low & Medium \\
\end{tabular} & High \\
\hline & & & \begin{tabular}{l|l} 
Medium & High \\
\end{tabular} & High \\
\hline Ravelling & $\begin{array}{l}\text { Progressive loss of pavement } \\
\text { materials like aggregate and } \\
\text { bituminous binder, which } \\
\text { results in a rough surface that is } \\
\text { vulnerable to weather } \\
\text { deterioration. }\end{array}$ & $\begin{array}{l}\text { - Aggregate or binder } \\
\text { starts wearing away } \\
\text { in some areas } \\
\text { - The surface starts to } \\
\text { pit. } \\
\text { - Oil stain can be } \\
\text { seen but the surface } \\
\text { cannot be } \\
\text { penetrated with a } \\
\text { coin. }\end{array}$ & $\begin{array}{l}\text { - Aggregate and/or } \\
\text { binder has worn } \\
\text { away, } \\
\text { - The surface texture is } \\
\text { rough and pitted } \\
\text { - Loose particles exist } \\
\end{array}$ & $\begin{array}{l}\text { - Aggregate and/or } \\
\text { binder has worn } \\
\text { away, } \\
\text { - The road surface is } \\
\text { very rough and } \\
\text { pitted < } 13 \mathrm{~mm} \\
\text { deep for an area of } \\
>1 \mathrm{ft}^{2}\end{array}$ \\
\hline $\begin{array}{l}\text { Block } \\
\text { cracking }\end{array}$ & $\begin{array}{l}\text { Interconnected cracks that } \\
\text { divide the pavement into } \\
\text { approximately rectangular } \\
\text { pieces caused by shrinkage of } \\
\text { asphalt pavement and daily } \\
\text { temperature cycling. }\end{array}$ & $\begin{array}{l}\text { - Crack width } \leq 6 \\
\text { mm, or } \\
\text { - Sealed cracks in } \\
\text { good condition with } \\
\text { negligible width. }\end{array}$ & $\begin{array}{l}\text { - Crack width } 6-19 \\
\text { mm with random } \\
\text { cracks }\end{array}$ & $\begin{array}{l}\text { - } \text { Cracks width }>19 \\
\text { mm, or } \\
\text { - Crack width } \\
\leq 19 \mathrm{~mm} \text { with } \\
\text { moderate to severe } \\
\text { random cracks. }\end{array}$ \\
\hline $\begin{array}{l}\text { Bumps and } \\
\text { sags }\end{array}$ & $\begin{array}{l}\text { Localized upward } \\
\text { displacements of the pavement } \\
\text { surface caused by infiltration } \\
\text { and build-up of material in a } \\
\text { crack in combination with } \\
\text { traffic load. }\end{array}$ & - Decent ride quality. & - Fair ride quality & - Poor ride quality. \\
\hline Corrugation & $\begin{array}{l}\text { A series of closely spaced } \\
\text { ridges and valleys occurring at } \\
\text { fairly regular intervals } \\
\text { perpendicular to the traffic }\end{array}$ & - Decent ride quality & - Fair ride quality. & - Poor ride quality. \\
\hline
\end{tabular}


Suspended Road System on Peat: A Case Study in Sibu, Malaysia

\begin{tabular}{|c|c|c|c|c|}
\hline & $\begin{array}{l}\text { direction, which is usually } \\
\text { caused by traffic action } \\
\text { combined with an unstable } \\
\text { pavement surface or base }\end{array}$ & & & \\
\hline Depression & $\begin{array}{l}\text { Localized settlement of } \\
\text { pavement due to improper } \\
\text { construction. }\end{array}$ & - $13-25 \mathrm{~mm}$ deep & - $25-50 \mathrm{~mm}$ deep & - $\geq 50 \mathrm{~mm}$ deep \\
\hline $\begin{array}{l}\text { Lane/ shoulder } \\
\text { drop-off }\end{array}$ & $\begin{array}{l}\text { Settlement or erosion of the } \\
\text { pavement edge and shoulder. }\end{array}$ & - $25-50 \mathrm{~mm}$ & - $50-100 \mathrm{~mm}$ & $\bullet \geq 100 \mathrm{~mm}$ \\
\hline $\begin{array}{l}\text { Patching/ } \\
\text { patching } \\
\text { deterioration }\end{array}$ & $\begin{array}{l}\text { An area of pavement replaced } \\
\text { with new materials for } \\
\text { repairing the existing } \\
\text { pavement or for installation of } \\
\text { underground utilities. }\end{array}$ & $\begin{array}{l}\text { - Low } \\
\text { distress } \\
\text { - Rutting < } 6 \mathrm{~mm} \\
\text { - } \text { pumping not } \\
\text { evident } \\
\text { - decent riding } \\
\text { quality }\end{array}$ & $\begin{array}{l}\text { - Moderate severity } \\
\text { distress } \\
\text { - Rutting } 6-12 \mathrm{~mm}\end{array}$ & $\begin{array}{l}\text { - } \text { Patch badly } \\
\text { deteriorated, } \\
\text { - Poor ride quality } \\
\text { - } \text { Rutting > } 12 \mathrm{~mm} \text {. }\end{array}$ \\
\hline $\begin{array}{l}\text { Polished } \\
\text { aggregate }\end{array}$ & $\begin{array}{l}\text { Smoothen pavement surface } \\
\text { with low friction due to wear- } \\
\text { outs by repeated traffic } \\
\text { applications. }\end{array}$ & \multicolumn{3}{|c|}{ Severity level not defined } \\
\hline $\begin{array}{l}\text { Slippage } \\
\text { cracking }\end{array}$ & $\begin{array}{l}\text { Crescent-shaped cracks } \\
\text { transverse to the direction of } \\
\text { travel, which are produced } \\
\text { when braking or turning } \\
\text { wheels that cause the pavement } \\
\text { surface to slide or deform. }\end{array}$ & $\begin{array}{l}\text { - Crack width }<10 \\
\mathrm{~mm}\end{array}$ & $\begin{array}{l}\text { - } \text { Crack width } 10-40 \\
\text { mm } \\
\text { - Moderately spalled } \\
\text { - Surrounded by } \\
\text { secondary cracks }\end{array}$ & $\begin{array}{l}\text { - Crack width } \geq 40 \\
\text { mm } \\
\text { - the area around the } \\
\text { crack is broken into } \\
\text { easily removed } \\
\text { pieces }\end{array}$ \\
\hline
\end{tabular}

